\title{
Learning History on High School Equivalency Program
}

\author{
Ranulin Windarsari ${ }^{1}$, Sunardi $^{2}{ }^{,}$Djono $^{3}$ \\ 1 Postgraduate Program of Historical Education, Sebelas Maret University, Surakarta \\ 2 Lecturer of Postgraduate Program of Historical Education, Sebelas Maret University, Surakarta \\ 3 Lecturer of Postgraduate Program of Historical Education, Sebelas Maret University, Surakarta \\ 1ulin_ran@yahoo.co.id, 2narfi_ip@uns.ac.id,33djono_sk@yahoo.com
}

\begin{tabular}{ccc}
\hline Received & Accepted & Published \\
$02 / 04 / 2017$ & $15 / 06 / 2017$ & $31 / 07 / 2017$ \\
\hline & DOI & \\
& $10.26523 /$ yupa.v1i2.56 \\
\hline
\end{tabular}

\begin{abstract}
This study is aimed to describe the implementation of learning history in high school equivalency programs. This study uses the descriptive qualitative method. Data were collected by interviews, documentation, and observation. Data analysis technique use qualitative analysis inductive models with purposive sampling technique. The results of this study are: first, planning learning history in high school equivalency program started from In-House Training for educators in high school equivalency program which practiced in the preparation of the learning device are appropriate to the curriculum; second, the implementation of learning history in high school equivalency program involves three patterns of learning consisting of $20 \%$ face-to-face interaction, 30\% tutorials, and 50\% independent activity; third, constraints in the implementation is the readiness of learners in receiving learning materials, learning infrastructure, and the competence of educators in conveying the teaching of history; fourth, evaluation of learning history in high school equivalency program is equal to the formal school.
\end{abstract}

Keywords: learning history, non-formal education, high school equivalency program

\begin{abstract}
Abstrak Penelitian ini bertujuan untuk mendeskripsikan pelaksanaan pembelajaran sejarah pada program kejar Paket C. Penelitian ini menggunakan metode deskriptif kualitatif. Pengumpulan data dilakukan melalui wawancara, dokumentasi dan observasi. Teknik analisis data yang digunakan adalah analisis kualitatif model induktif dengan teknik purposive sampling. Hasil penelitian antara lain: pertama, perencanaan pembelajaran sejarah pada program kejar paket $C$ dimulai dari pelatihan In House Training bagi para pendidik program kejar paket $C$ yang dipraktikan dalam penyusunan perangkat pembelajaran yang disesuaikan dengan KTSP; kedua, pelaksanaan pembelajaran sejarah pada program kejar paket $C$ meliputi tiga pola pembelajaran yang terdiri dari tatap muka 20\%, tutorial 30\%, dan kegiatan mandiri 50\%; ketiga, kendala pelaksanaan adalah kesiapan peserta didik dalam menerima materi pembelajaran, sarana prasarana pembelajaran, serta kompetensi pendidik dalam menyampaikan pembelajaran sejarah; keempat, Evaluasi pembelajaran sejarah pada program kejar paket $C$ sama dengan sekolah formal.
\end{abstract}

Kata kunci : pembelajaran sejarah, pendidikan non formal, program kejar paket $C$ 


\section{INTRODUCTION}

Today education is a necessity for society because education is a key aspect for one's future. Education, in general, is believed to hold the power to create an overall vision of life in creating human civilization (Jannah, 2013: 3). Education has a link with various efforts in improving the quality of human life as a whole. The effort of education is realized in the development of the whole human potential to the more mature and functional direction so that creatively can give birth to various patterns of behaviour in accordance with the demands of the task in life.

The development of education is directed to produce a smart and competitive Indonesian society through increased availability, affordability, quality and relevance, equality and certainty of education. Education takes place throughout life in accordance with the development of the demands of the tasks of students and the development of increasingly complex society. However, education can also lead to social inequalities that become social barriers in society because not all get a decent education. Therefore, the government's efforts to implement an education that can be enjoyed by all the so-called equivalence education which is part of non-formal education. Non-formal education in accordance with its function as a substitute, enhancement and/or complementary education can be given to people who have special conditions (Hermawan, 2012: 65-66). One of the various programs of non-formal education is through equivalency education which includes Package An equivalent of elementary school (6 years), Package B equivalent to junior high (3 years), and Package C equivalent of SMA (3 years).

The implementation of equivalency education refers to the applicable curriculum. The curriculum is a set of plans and arrangements concerning the objectives, content and lesson materials as well as the ways that are used as guidelines for the implementation of learning activities to achieve certain educational objectives covering the goals of national education and conformity with uniqueness, conditions and potential areas, educational units and learners. Therefore, the curriculum is composed of educational units to enable the adjustment of educational programs to the needs and potentials of the region. One of the providers of equivalency education is SKB Sukoharjo by using curriculum that is applied that is KTSP that develops cultural values and character of the nation as a unity of educational activities that occur in schools.

Law no. 20 of 2003 on National Education System clearly states about the function of education for the formation of attitudes, character and personality of learners. History lessons have a strategic meaning in the formation of the character and civilization of a dignified nation and in the formation of Indonesian people who have a sense of nationality and love of the 
country. Therefore, historical learning is indispensable to education in Indonesia both through formal and non-formal education.

\section{METHOD}

The type of this research is descriptive research with a qualitative approach. According to (Sugiyono, 2010: 1), qualitative research method is a research method used to examine the condition of natural objects. The data analysis is inductive and the result of the research emphasizes the meaning of the generalization. The strategy used in this research is a case study. A case study is a more suitable strategy if the subject of a question concerns how or why, the researcher has little chance of controlling the events to be investigated, and the focus of the research lies in the contemporary phenomenon in a real-life context (Yin, 2002: 1). This research is a qualitative research, the sampling technique used is a sampling technique that is purposive sampling (purposive sampling), where researchers tend to choose informants who are considered to know and can be trusted completely as a source of data and know the problems in depth (Sutopo, 2006: 64).

Data collection using observation techniques, interviews, and document analysis. Observations were made to obtain data in the field of the historical learning process in Sukoharjo SKB. Interviews were conducted with participants in this study consisting of: head of SKB Sukoharjo, Chairman of SKB Sukoharjo, Chief Package Management High School Equivalency Program SKB Sukoharjo, educator or history tutor, learner or studying citizen at SKB Sukoharjo recorded as a data source. Documents are required to complement other data sources. In maintaining the validity of the research, using triangulation techniques, re-checking, and self-reflection. Triangulation is a technique used in qualitative research to check and build validity by analyzing data from various instruments. Triangulation used in this research is a triangulation of source and triangulation method (Patton, 2009: 99).

Observational data are recorded with field notes and presented in the descriptive form. The research used is qualitative inductive meaning that all conclusions made up to the possible theory are developed, formed from all data that have been found and collected in the field (Sutopo, 2006: 64). This study uses interactive model analysis techniques including three components of analysis that is data reduction, data presentation and drawing conclusions or verification. The three components of the analysis are conducted interactively and continuously. At the beginning of the study conducted data collection which further sought meanings, patterns, explanations, configurations, causal paths, and propositions. Data reduction is a form of analysis that sharpens, classifies, directs, discards the unnecessary, organizes the data in such a way that it can be done verification or drawing conclusions. The second plot is by presenting a set of arranged information that gives the possibility of conclusions and taking action. The 
presentation of the data shown can be understood what is going on and what to do. The third activity of analysis is to draw conclusions and verification (Milles \& Hubeman, 2002: 16-19).

\section{RESULT AND DISCUSSION}

This research was conducted at SKB "Bina Mandiri" Sukoharjo, high school equivalency program with an address at Jalan Pemuda No.75 Sukoharjo. SKB Sukoharjo is one of the nonformal education providers in Sukoharjo District under the auspices of Sukoharjo District Education Office. SKB Sukoharjo is one of the Regional Integrated Service Units which is an organization under the District Education Office Sukoharjo under Non-formal Education. SKB was established based on Ministry of Education and Culture Decree of Indonesia No 039/0/1998 on February 23, 1998, after the regional autonomy of the existence of LCS is regulated by Regional Regulation No 17 the year 2001 on Establishment, Position, Main Task, Function and Organizational Structure of Education Office of Sukoharjo Regency and Decision of Bupati No 28 of 2001 on the Elaboration of Main Duties and Functions of Sukoharjo District Education Office. The purpose of the founding of the LCS is to serve out-of-school education for people in need of skills. Sukoharjo District Education Office is one form of non-formal education implementation in Indonesia. Non-formal education is education that is held outside the school education path, whether institutionalized or not institutionalized, and not necessarily tiered and sustainable (Abdulhak \& Suprayogi, 2011: 17).

The variety of non-formal education programs in Indonesian society is one of them through equality education. Equality education is non-formal education aimed at citizens who have no chance of a formal education in school. It is known as the Patient (Study Group) Package A for the SD equivalent, Package B for the equivalent of SMP, and Package C for the equivalent of SMA, as well as the Functional Literacy Program, to serve illiterate citizens. Graduates of non-formal education are recognized as equivalent to formal education (Permendiknas No. 23/2006 on Graduate Competency Standards). The consequence of equality programs is that there is a need for quality improvement that is equivalent or equal to the function of formal education in meeting the needs of community education (Desmawati, 2011: $1)$.

Curriculum applicable in Sukoharjo SKB is Education Unit Level Curriculum. National Education Standards Article 1 paragraph 15 stated that Education Unit Level Curriculum is an operational curriculum developed and implemented by each educational unit. The formulation of KTSP is carried out by the education unit by taking into account and based on the standard of competence and basic competence developed by the National Education Standards Agency (Mulyasa, 2009: 19-20). In this sense, autonomy through Education Unit Level Curriculum is an implication of a centralized policy change to decentralization in education. 
Education Unit Level Curriculum on equality education package A, B and C is the operational curriculum established by the regency/city education office and implemented in each educational unit. The operational curriculum for equivalency education programs consists of educational goals, Structure and curriculum content, Education calendar, and Syllabus. The structure and content of the KTSP Equivalency Education Program include Religious and noble subject groups, Civics and personality classes, Science and technology subjects, Aesthetic subject groups, and Physical, Sports and Health subject classes. The group of subjects is conducted through the content and learning activities as described in PP. 19 of 2005 article 7 that the Education Unit Level Curriculum content covers a number of subjects whose flexibility and depth is the burden of learning for learners in the unit of education, in addition to the content of local content and self-development activities included in the contents of the curriculum (Puspawati, 2012). The program curriculum structure of Package A, Package B, and Package $C$ is a pattern of subject arrangement and learning load that must be pursued by learners in learning activities, covering subjects, and weight of credit units of competence.

One of the structures of these subject groups is the presence of historical learning. History is a branch of science that examines the origin and development and role of society in the past based on certain methods and methodologies. Equality education in Package A, B, C programs in non-formal education, past knowledge contains values of wisdom that can be used to train intelligence, shape the attitude, character and personality of learners or learners. One effort to shape the character and personality of the nation is through historical education. The need to teach young people the fundamental values of humanity and noble morality so that young people are not fragmented in culture, ethnicity, and religion is urgent to do so in order not to become the trigger of the division of national unity. According to Azra in Niron, Budiningsih, and Pujiriyanto (2013: 19-31) studies stated that multicultural education and nation character must be pursued systematically, programmatically, integrated and continuously through all educational institutions, formal, non-formal and even informal. For this purpose, it is necessary to integrate the supporting aspects in order to solve this national strategic problem more focused, comprehensively and efficiently.

Special lessons on history are studied in the equivalency education of Package $C$ programming. High school equivalency is one of the basic education programs organized through the Out of School education line. Outside school education works to develop the potential of learners/citizens of learning with an emphasis on mastery of knowledge and functional skills and the development of professional attitudes and personalities. Package $\mathrm{C}$ program is one of the efforts made by the government to provide opportunities for school-age and adult age people who for various reasons not continue their education (Ciptasari, 2015: 116). 
Good learning starts from the beginning of good planning as well. Learning planning should be done by the educator before the learning activities are implemented. Planning is made first so that in the implementation of learning can run smoothly and can achieve the purpose of learning. A planning must start from the goal setting that will be achieved through a needs analysis which then determined the steps that must be done to achieve that goal. Agung and Wahyuni (2013: 22) suggested that learning planning is the process of translating the curriculum into learning programs. Programs that must be prepared by educators include arranging time allocation, annual program, semester program, syllabus, and RPP based on SBC. Before the implementation of the lesson begins the tutor must first plan the learning programs that must be prepared in the learning tool.

Learning history planning done by tutor at Sukoharjo District Education Office is by arranging learning tools which previously tutor has been given training by managers of Non Formal Education Indonesia (PNFI) through In-House Training (IHT) in Semarang and get knowledge about implementation of learning planning in Learning Activity Studio attended by the tutors appointed by the equivalency education unit. The tutor should also understand the circumstances of the different learners from the condition of the learner in the formal school, the education available in the high school equivalency program using the pedagogy and andragogy approach.

The implementation of In-House Training by the central government of PNFI organizers is in line with Sutisna's research (2015: 93-101) stating that a continuous technical guidance model to improve the competence of $\mathrm{C}$ package tutor in learning is the chosen alternative to achieve the goal by developing a model of sustainable technical guidance, focus on the competence of tutors in carrying out the task of learning, so that after following the guidance can increase the competence of learning. The development of technical counselling model is based on the idea that the process that has been carried out so far is partial, cognitive oriented and the implementation is very conventional and the material is not in accordance with the needs of the participants. The training given to the $\mathrm{C}$ package program tutors are aimed at improving the professionalism of tutors in performing their duties as educators in the high school equivalency.

Preparation of the implementation of learning on Sukoharjo District Education Office according to starting with training tutors such as the implementation of In-House Training (IHT) held by inviting a number of competent sources in education outside the school which contains training on the preparation of learning tools and training KBM online in 2015 followed by all tutor SKB. However, IHT implementation only takes place incidentally or not routinely. This is reinforced by the statement of history tutor ever sent as one of IHT participants. Preparation of learning tools in the program chase package $C$ is basically the same as the 
preparation of learning tools education formal education. However, there is a difference between the formal school learning tool and the equivalency education that is the identity of the school is changed to the identity of the LCS, the principal's identity is replaced by the identity of the head of the LCS, and the learning activities for the LCS are changed to face-to-face by $20 \%$, tutorials by $30 \%$, and independent activities by $50 \%$.

A professional educator is an educator who performs the duties and responsibilities of his profession well so that it is necessary to master the curriculum along with the implementation instructions, have the ability in preparing the learning program in the form of lesson plans, understand and follow up the learning process. The competence of history tutor in the process of preparation of learning tools in Sukoharjo District Education Office is said enough. This can be seen in the documents of learning tools made by historical tutors at Sukoharjo District Education Office which have not shown the characteristics or characteristics of the $\mathrm{C}$ package equality education other than the learning patterns. Learning history tools compiled by history tutors also did not experience significant changes from year to year. KTSP enforces the broadest possible autonomy to education providers to develop education in Indonesia, including providing autonomy to educators, in this case, is a tutor to devise a good and creative learning tool. A learning tool is almost the same as on the internet that can be downloaded by many people.

The history learning strategy used by the tutor has not yet shown the creativity of the tutor. The process of learning history in Sukoharjo District Education Office felt by some students is very boring. One learner suggests that history's learning is full of memorization so it is difficult to digest many of the names of figures and dates. Thus, the right learning strategy is needed so that the learning process can achieve the goals that have been set. This is reinforced by Misco \& Petterson (2009: 86) that the problems that lie in the mismatch, weakness of meaning, and boring learning experience are a real picture in the process of learning history.

The method used by tutors in teaching history in Sukoharjo District Education Office only varied lectures and question and answer. This is because the state of learners or learners who do not like learners in formal schools. Learning strategy planning is also not prepared carefully by the tutor due to the circumstances of citizens who have learned all day working so as not to be able to digest the learning in the afternoon. Lesson strategies that are not prepared by the tutor are also due to the tutor's lack of understanding of the strategies used in historical learning. During the process of face-to-face teaching and learning activities in history, tutors only explain the learning materials with more portion of a textbook with lecture method varies.

Safe' research (2012: 454) shows that the quality of learning history consists of seven components, namely: the performance of history teachers, historical lesson materials, learning methods, learning means of history, classroom climate, student attitudes, and learning history 
motivation. While the learning outcomes of history consist of three components namely: academic skills, historical awareness, and attitude of nationalism. Another factor that determines the success of history learning according to Soepardjo (2013: 125) is the role of teachers in learning history, social environment, school environment and family environment and the stability of physical and mental health of students. The attitude of nationality needs to be developed through the process of education in schools because the schools as the printing institutions of the nation's cadres are democratic, capable, love of the nation and the country and are responsible for the survival of the nation in the future.

Based on some of the above opinion is emphasized the role of the tutor as an educator to achieve the purpose of learning history in accordance with characteristic character formation of the nation. Self-reliance in quality education is necessary to build the creativity of learners or learners. Individual activities are usually done outside the hours of Teaching and Learning Activities (KBM). In the independent activities, tutors usually give individual tasks to observe the environment (observation) where each learner lives. For example in class $\mathrm{X}$ material there is learning the material of Indonesian tradition before know writing, hence learners to observe nyadran culture, tingkeban, mitoni, tedhak siten, traditional game, and others which then reported in written form.

The above is supported by the research of Suyitno, Kamal, Sunoto, \& Suherjanto (2016: 15) stating that the environmental context is an important factor in developing teaching and learning activities. This is based on the reason that in carrying out his life, students will always depend on the environment where he lives. The relationship between the student's life and the environment is not merely manifested as a relationship of human dependence on his environment, but also manifested as a relationship of mutual influence. The background of different learning residents with learners in formal education could be observed by a tutor with using strategies, methods, and good learning model that causes during the learning process tends to monotonous. Tutor fully master the process of KBM. During the KBM process, historical learning patterns in Sukoharjo SKB are tended to use lectures. Tutors felt lack of personal attachment to learners or learners so that less understanding of the needs of citizens to learn in the classroom so that the learning atmosphere becomes awkward and less excited.

Tutors such as Waspodo's research (2009: 63-69) should be able to implement andragogical approaches through the concepts of learners, learners' learning functions, learning readiness and learning orientation. The role of educator/tutor in andragogy approach as a facilitator to prepare tools or procedures to actively encourage and engage all learners/learners through a participatory approach. This will create an active, innovative, competitive, effective, and fun learning environment. Examples of learning through participatory approaches are 
through group discussion activities. However, in practice at Sukoharjo District Education Office, the tutor, despite having had discussion activities expected on the outcome, will be the same as a formal school, but the results are different. Learners or learners take advantage of discussion activities to tell stories outside of the material being discussed or lack of understanding of the discussion material so that the discussion felt not in accordance with the initial goal of making learners become active, creative, and innovative. Daryanto (2009: 172-173) states that the implementation of learning is a process of interaction between trainees and teachers who use all the resources in accordance with the planning that has been prepared in advance in order to achieve the goal. Implementation of learning should always remember the principle of learning that is by channelling the key competencies in every activity and activity that is always centred on the participants of education and training.

Implementation of learning history in Sukoharjo District Education Office using 3 patterns of learning activities are face-to-face as much as $20 \%$, tutorials as much as $30 \%$, and independent as much as $50 \%$. However, during past history learning practices in actual practice it is more dominant in the face-to-face and tutorial implementation than on independent implementation, because the learning residents are expected to learn independently and creatively outside the SKB then it will not be able to walk. This is reinforced by the opinion of history tutors at SKB stating that the character of learners or residents learns Sukoharjo District Education Office still need guidance from the tutor, so that in the implementation of less learning in accordance with learning tools. In the delivery of learning materials, tutors are considered boring and monotonous by the learners because the teaching tutor in a way or teaching method varies lectures and with a less loud voice, as well as closeness with learners or residents who are less familiar learning so that the learning atmosphere becomes rigid and calm. Lecture method varies is the most suitable method applied in Sukoharjo District Education Office because the state of learning is not like in a formal school where learners can focus on learning while the majority learn to work or help parents at home.

The purpose of teaching is not just the transfer of knowledge, but also the transfer of value, not just teaching students to be smart, but also noble. The teaching of history in addition to aims to develop scholarship also has a didactic function. Didactic function of teaching history has been expressed implicitly and explicitly, as stated by Sartono Kartodirdjo in Supardi (2014: 94) stated that the purpose of teaching history is for the younger generation to take lessons and lessons from the experience of his ancestors. Implementation of history learning in Sukoharjo District Education Office in order to cultivate the value of the national character to learners is less because learners who understand the meaning of learning history is only a few students only. 
This is in accordance with the opinion Tuahunse (2009: 32) which states that if the process of teaching and learning history is well managed and professionally, of course, the result is more satisfactory. For this reason, the role of history teacher is very decisive in the success of teaching and learning, especially for the delivery of historical materials required learning models with variations of methods suitable so that students can understand the values contained from various events of Indonesian history.

The teaching material of history at Sukoharjo District Education Office is similar to the learning material in formal school in general which is in accordance with the applicable Curriculum, which is SBC elaborated through syllabus, RPP, KKM, time allocation, effective weeks' breakdown, and others with the characteristic of learning SKB provide skills for learners tailored to the learning materials. As an example of what history tutors say has ever given independent tasks such as the simple "sungging tatah" of cloth associated with acculturation learning materials of Hindu-Buddhist and Islamic cultures in Indonesia. Sungging Tatah is a sewing technique for wayang or calligraphy that comes from the skin. Sukoharjo has a leathermaking industry that adapts to learning materials and vocational skills taken by learners. However, it can't be proved through during field observation and is not included in the document of class XI learning device.

Things that can affect the success of the learning process include educator factors, factors learners, facilities and infrastructure factors, and environmental factors. So these things that cause obstacles implementation of learning history. Educators are the main components that determine the success of a learning system. This is because educators are people who are directly dealing with learners. Educators in a learning system can act as planner or learning designer and as an implementer. Educators as planners are required to understand the applicable curriculum, the characteristics of learners, facilities, and existing resources so that all of them become components in preparing plans and instructional design. Educators as implementers of lesson plan not only serve as models or role models for learners but also as teach managers (Agung and Wahyuni, 2013: 44). Tutor as educator less than the maximum in the service of learning history. The compilation of instructional tools that tend to be the same as formal schools without showing the hallmark of equity education and delivery methods using only commonly used strategies, methods and learning models do not show the characteristics of historical learning at Sukoharjo District Education Office.

This is reinforced by Azhar's (2011: 22) study which states that the learning model in entrepreneurship education and training uses curriculum developed and developed on the basis of people's needs that are oriented towards livelihoods and improving the lives of studying citizens; facilitator activities in the form of providing entrepreneurial learning in the form of mentoring production, marketing, and self-employment entrepreneurship of learning citizens; 
active learning citizens attending entrepreneurship education and training as well as developing and expanding business; and learning methods are implemented simulations and group discussions, with andragogical approaches, practical and flexible, application of learning materials for income generation by learning and doing (learning by doing) around improving everyday life. Based on Azhar's opinion when applied in teaching history at Sukoharjo District Education Office same that is putting on skill training of learners in lesson material taken as stock to face life in the future. For example in the material acculturation of Hindu-Buddhist culture, and Islam there are cultural results in the form of wayang. Wayang is one home industry developed by Sukoharjo regency government. Learners get skills from SKB in the form of sewing skills applied in the learning materials by making a simple wayang through the process of sewing and the introduction of techniques "tungah sungging".

Skill-based learning (soft skills) has a link with the character education campaign to build the nation. Soft skills learning as part of character education has the function of shaping the character of workers. Character education at the class level is one of the functions of forming the character of professional workers. Implementation of character education at the class level should have the function of strengthening the nation's character as a nation that is intelligent, superior and dignified. As a culinary expert, planting characters in both production and managerial fields will give birth to quality-based students; work fast, precisely, and efficiently; respect time; maintaining reputation; noble character; disciplined; and independent (Hamidah, Rahmawati, \& Jaedun, 2013, pp.165-166). This also applies to the implementation of history learning at Sukoharjo District Education Office which emphasizes on skill education adapted by shaping the nation's character through simple wayang sewing skills.

Obstacles encountered during the process of learning history implementation took place in other Sukoharjo District Education Office lies in the state of learners. Students who come to Sukoharjo District Education Office have a goal not to gain knowledge, but to get a diploma equivalent to high school. In addition, the condition of learners that most have been working cause SKB managers and tutors difficulties in the implementation of learning, especially if it has been evaluating the learning.

Student factors also become one of the success factors of the learning process. Learners have different abilities that can be grouped into high-ability, moderate, and low students (Agung and Wahyuni, 2013: 46). However, students on Sukoharjo District Education Office have the same average ability. Based on research Retnawati, Kartowagiran, Hadi, and Hidayati (2011: 162-174) mentioned that the difficulty of learners in learning one of them based on absorption in receiving learning materials and learning materials are perceived difficult by learners. The same context in historical learning at Sukoharjo District Education Office is the absorption of learners that are not the same as learners in formal schools. 
A historical tutor who acts as an educator at Sukoharjo District Education Office knows the curriculum applicable to Sukoharjo District Education Office is unit level education curriculum wherein the preparation of learning tools adapted to the applicable curriculum. Historical tutors at Sukoharjo District Education Office are also able to understand well the circumstances of citizens studying in Sukoharjo District Education Office which is different from learners in formal school. The condition of citizens learns as learners Sukoharjo District Education Office in a state already working, so that the process is adapted to the circumstances of the learning community. Based on this, the history tutor at Sukoharjo District Education Office in actual implementation in the field does not use any strategies, methods, or learning models that confuse learners, so the most suitable are applied only varied lectures and frequently asked questions.

Implementation of good learning is also supported by the means of pre-facilities provided by the educational unit, in this case, is Sukoharjo District Education Office. Completeness of facilities and infrastructure can help educators in organizing the learning process (Agung and Wahyuni, 2013: 47). Supporting facilities and infrastructure of learning at SKB Sukoharjo already available is good enough, especially based on IT like wifi facility. In addition, the availability of supporting books tailored to the $\mathrm{C}$ program package is used in the implementation of the teaching and learning process. Teaching and learning supporting books have difficulty in terms of how to get it. This is because not all book publishers publish a special handbook for equality education.

The last stage in learning history at Sukoharjo District Education Office is an evaluation. Evaluation is the process of giving meaning or determination of the quality of measurement results by comparing the figures of the measurement results with certain criteria. Evaluation is conducted with the intention to know the extent to which the quality achievement of program implementation and success level of program implementation. In the $C$ package equality program, there are two types of evaluation, namely: evaluation of the implementation, an activity to evaluate or correct the things that have happened or done during the implementation of the program is or has been in progress in the hope that it can make improvements during the program implementation activities next, and evaluate the development of learners with a view to knowing the progress of learners' learning outcomes over a period of time and to find out the effectiveness of the learning methods and approaches taken over a period of time (Technical Guidance for Equal Education Program Package C 2016: 18-19).

Evaluation of history learning in Sukoharjo District Education Office includes cognitive, affective, and psychomotor can be done through group tasks and individual tasks usually given at the time of learning activities in the SKB either tutorial or at the time of independent 
activities. The evaluation includes portfolio assignments, daily tests, mid-semester tests, and semester exams. Assessment process done by the tutor at the time of teaching and learning process is by assessing the activeness of learning in the class. Assessment is used to determine the level of ability and absorption of learning citizens in learning history. Assessment on LCS is already listed on the learning tool and determined in Minimum Completion Competency through minimal learning completeness analysis on each indicator by considering the complexity, carrying capacity, intake of 75 in accordance with the national mastery target. Constraints in the implementation of evaluation in Sukoharjo District Education Office are learners. Students who have worked less can determine the right time to carry out evaluation together. Therefore, it requires activeness from the manager of the LCS and the tutor to contact the students concerned in order to follow the evaluation as a condition to proceed to the next level.

\section{CONCLUSION}

Based on the results of the above research can be concluded as follows. First, the planning of history learning in Sukoharjo District Education Office is good enough through the early stages of In-House Training which is given to tutors or educators to arrange learning tools in accordance with the high school equivalency program with the applicable curriculum is SBC which then develops up to strategy, methods, learning models used, and evaluation of learning. Second, the implementation of history learning in Sukoharjo District Education Office is implemented in accordance with the learning tools made by the tutor with the same learning materials as the formal school. The difference with the formal school in the execution of learning history lies in the learning patterns in high school equivalency program covering the activities of face to face is $20 \%, 30 \%$ for tutorial activities, and $50 \%$ for independent activities. Third, the obstacles in the implementation of learning history on the high school equivalency program in Sukoharjo District Education Office is the mental readiness of learners or learning citizens in receiving learning materials, provided infrastructure facilities, and the competence of educators in conveying historical learning. Fourth, the evaluation of history learning in high school equivalency program in Sukoharjo District Education Office is the same as a formal school which includes cognitive, affective, and psychomotor competence.

Based on the results of this study, it is expected that there are often training conducted to SKB tutors or educators to be more professional, the facilities, supporting facilities and infrastructure in implementing historical learning process, as well as objective assessment of the education department or program manager chase of high school equivalency program against performance tutor. In addition, tutors should have a great responsibility towards the learning process of history at Sukoharjo District Education Office. An educator must do the job 
professionally and maximally serve the needs of the learning community and must support every implementation of the existing learning with the maximum.

\section{REFERENCES}

Abdulhak, I. \& Suprayogi, U. 2011. Penelitian Tindakan dalam Pendidikan Nonformal. Jakarta: PT. Raja Grafindo Persada.

Agung S., L \& Wahyuni, S. 2013. Perencanaan Pembelajaran Sejarah. Yogyakarta: Penerbit Ombak.

Aman. 2012. Pengembangan Model Evaluasi Program Pembelajaran Sejarah di SMA. Jurnal Penelitian dan Evaluasi Pendidikan. 16 (2). 437-456.

Azhar. 2011. Model Pembelajaran Kewirausahaan pada PKBM Binaan SKB Kabupaten Temanggung. Jurnal Kependidikan. 41 (1), 11-22.

Ciptasari, D. R. 2015. Manajemen Program Pendidikan Kesetaraan Kejar Paket C "Harapan Bangsa" di UPTD SKB Ungaran Kabupaten Semarang. Journal of Non Formal Education and Community Empowerment, 4 (2), 115-120.

Daryanto. (2009). Panduan Proses Pembelajaran Kreatif dan Inovatif: Teori dan Praktik dalam Pengembangan Profesionalisme bagi Guru. Jakarta: AV Publisher.

Desmawati, L., Suminar, T., \& Budiartati, E. 2011. Penerapan Model Pendidikan Kecakapan Hidup pada Program Pendidikan Kesetaraan di Kota Semarang. Semarang: UNNES.

Hamidah, S., Rahmawati, F., \& Jaedun, A. 2013. Pembelajaran Soft Skills Terintegrasi Bagi Penumbuhan Karakter Pekerja Profesional Bidang Boga. Jurnal Kependidikan, 43 (2), 164-173.

Hermawan, I. K. D. 2012. Kinerja Pendidikan Kesetaraan sebagai Salah Satu Jenis Pendidikan Nonformal. Jurnal Pendidikan dan Kebudayaan, 18 (1), 65-84.

Jannah, M. 2013. Pendidikan Seumur Hidup dan Implikasinya. Jurnal Dinamika Ilmu, 13 (1). 1-16.

Miles, M.B. \& Huberman, A. M. 2002. Analisis Data Kualitatif. Terj. Tjetjep Rohendi R. Jakarta: UI-Press.

Misco, T. \& Petterson, N. C. 2009. An Old Fad of Great Promise: Reverse Chronology History Teaching in Social Studies Classes. Journal of Social Studies Research, 33 (1), 71-90.

Mulyasa, E. 2009. Kurikulum Tingkat Satuan Pendidikan: Sebuah Panduan Praktis. Bandung: PT. Remaja Rosdakarya.

Niron, M.D., Budiningsih, C.A., dan Pujiriyanto. Rujukan Integratif dalam Pelaksanaan Pendidikan Karakter di Sekolah Dasar. Jurnal Kependidikan, 43 (1), 19-31.

Patton, M. Q. 2009. Metode Evaluasi Kualitatif. Yogyakarta: Pustaka Pelajar.

Puspawati, P. 2012. Penyusunan dan Pengembangan KTSP Program Pendidikan Kesetaraan. Diunduh di http://dikporasruweng.blogspot.co. id/2012/02/penyusunan-dan-pengembangan-ktsp.html diakses pada Jumat, 24 Juni 2016 pukul 13:31. 
Retnawati, H., Kartowagiran, B, Hadi, S, dan Hidayati, K. (2011). Identifikasi Kesulitan Peserta Didik dalam Belajar Matematika dan Sains di Sekolah Dasar. Jurnal Kependidikan, 41 (2), 162-174.

Soepardjo. 2013. Kontribusi Status Sosial Ekonomi Keluarga dan Sikap Kebangsaan terhadap Prestasi Belajar Sejarah. Jurnal Penelitian dan Evaluasi Pendidikan. 17 (1), 108-126.

Sugiyono. 2010. Memahami Penelitian Kualitatif. Bandung: CV. Alfabeta.

Supardi. 2014. Pendidikan Multikultural dalam Pembelajaran Sejarah Lokal. Jurnal Pembangunan Pendidikan: Fondasi dan Aplikasi, 2 (1), 91-99.

Sutisna, A. 2015. Pengembangan Model Bimbingan Teknis Berkelanjutan dalam Meningkatkan Kompetensi Tutor Paket C. Jurnal Ilmiah VISI PPTK PAUDNI, 10 (2), 93-101.

Sutopo, H. B. 2006. Metodologi Penelitian Kualitatif: Dasar teori dan Terapannya dalam Penelitian. Surakarta: Universitas Sebelas Maret.

Suyitno, I., Kamal, M., Sunoto, \& Suherjanto, I. 2016. Teknik Pembelajaran Observasi Lingkungan Berbasis Kearifan Lokal. Jurnal Kependidikan. 46 (1), 14-28.

Tuahunse, T. 2009. Hubungan Antara Pemahaman Sejarah Pergerakan Nasional Indonesia dengan Sikap Terhadap Bela Negara. Jurnal Kependidikan. XXXIX (2), 21-34.

Waspodo, M. 2009. Peran Tutor dalam Pembelajaran dengan Pendekatan Andragogi. Jurnal Ilmiah VISI, 4 (1), 63-70.

Yin, R. K. 2002. Studi Kasus: Desain dan Metode. Jakarta: PT Raja Grafindo Persada. 